\title{
SINERGISITAS PENDIDIKAN KARAKTER DI SEKOLAH, KELUARGA, PERGURUAN TINGGI, DAN MASYARAKAT
}

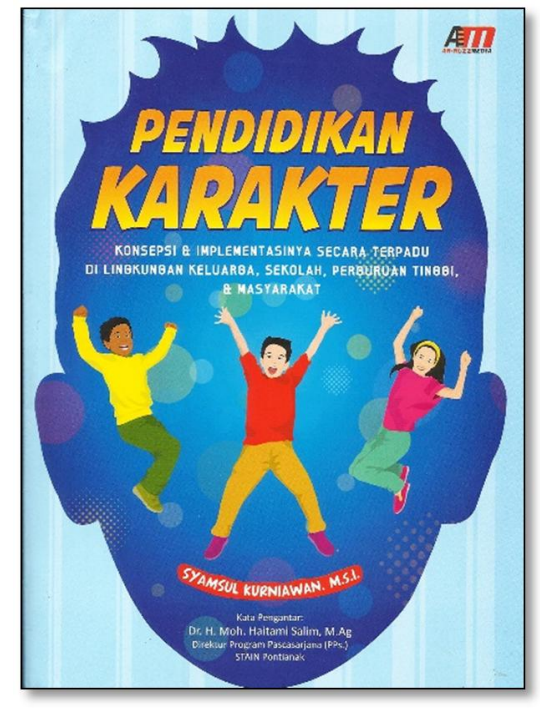

Judul Buku : Pendidikan Karakter: Konsepsi dan Implementasinya secara Terpadu di Lingkungan Keluarga, Sekolah, Perguruan Tinggi, dan Masyarakat

Penulis $\quad$ : Syamsul Kurniawan, M.S.I

Penerbit : Ar-Ruzz Media

Tahun Terbit : 2013

Tempat Terbit : Yogyakarta

Tebal Buku : 242 Halaman

Diresensi : Dian Kartika Sari, S. Kom.I (Staf di IAIN Pontianak)

Semakin meningkatnya degradasi moral di lingkungan masyarakat Indonesia saat ini menjadi tantangan tersendiri bagi dunia pendidikan Indonesia. Pendidikan yang diajarkan dan dibutuhkan saat ini tidak lagi melulu soal akademis dan kualitas intelektual, tapi juga pendidikan moral dan karakter kemanusiaan. Sistem pendidikan seperti yang dimaksud sebenarnya telah jelas diungkap pada UU No.20 tahun 2003 tentang Sistem Pendidikan Nasional pasal 4 ayat 1 yang menyebutkan, "Pendidikan nasional bertujuan membentuk manusia yang beriman dan bertakwa kepada Tuhan Yang Maha Esa, berakhlak dan berbudi mulia, sehat, berilmu, cakap, serta menjadi warga negara yang demokratis dan bertanggungjawab terhadap kesejahteraan masyarakat dan tanah air”. Sehingga, pendidikan karakter dirasa sangat perlu diterapkan guna meminimalisir kemerosotan moral anak bangsa.

Syamsul menulis buku Pendidikan Karakter: Konsepsi dan Implementasinya secara Terpadu di Lingkungan Keluarga, Sekolah, Perguruan Tinggi, dan Masyarakat ini bertolak dari kegelisahannya melihat penurunan moral yang terjadi di masyarakat. Mulai dari kenakalan remaja, kasus narkoba, kekerasan seksual, hingga maraknya kasus korupsi. Oleh karena itu, Syamsul memandang perlu adanya sistem pendidikan yang kuat dan berkarakter untuk diterapkan tidak hanya di sekolah dan perguruan tinggi, tapi juga di lingkungan keluarga dan masyarakat.

Pentingnya pendidikan karakter diterapkan dalam kehidupan sehari-hari dimulai dari lingkungan keluarga. Keluarga merupakan 'sekolah' paling pertama yang ditemui anak-anak calon generasi bangsa (sebagai peserta didik). Penanaman norma-norma kesusilaan dan pembentukan moral dalam diri seorang anak diawali dari lingkungan keluarga. Setelahnya 
barulah peserta didik menerima pendidikan formal di sekolah dan perguruan tinggi untuk meningkatkan kekuatan karakter yang telah tertanam sejak dini di lingkungan keluarga. Kemudian karakter yang telah terbentuk tersebut secara otomatis akan terimplementasi saat berinteraksi di masyarakat.

Buku ini sangat menarik untuk dibaca karena menyajikan secara komprehensif pentingnya pendidikan karakter di lingkungan keluarga, sekolah, perguruan tinggi, dan masyarakat, serta bagaimana keselerasan pendidikan karakter di semua aspek tersebut berimbas positif bagi para peserta didik. Ditulis dengan bahasa yang ringan dan mudah dipahami membuat buku ini layak untuk dijadikan pegangan khususnya bagi orangtua, guru, mahasiswa, serta pemerhati pendidikan. 